\title{
Computer-based peer assessment as a part of learning process
}

\author{
Komang Setemen ${ }^{1, *}$, Luh Joni Erawati Dewi ${ }^{1}$, and I Ketut Purnamawan ${ }^{1}$ \\ ${ }^{1}$ Management Informatics Department, Universitas Pendidikan Ganesha, Singaraja, Indonesia
}

\begin{abstract}
This study aimed to develop prototype of computer based peer assessment application. This application is used for learning assessment which involves the students in learning process, either individually or in group. This study was research and development (R\&D) model which adopted 4D model (Define, Design, Develop, and Disseminate). Prototype of this application was developed by utilizing internet media (online). The users of this system are lectures and students. In this application, the lecturers has roles to design the scoring rubrics, give the tasks, and assess the students' tasks. The students had roles to submit the tasks, and assess their pairs. Every kind of scoring rubrics can be implemented in some subject matters which have same characteristics (sharing rubrics). This application is expected to produce transparent, quick, correct, and accurate scoring. It is also efficient for lecturers in students assessment. The onlinebased application design will make this application become an electronic assessment which can be accessed whenever and wherever.
\end{abstract}

\section{Introduction}

The competence-based education paradigm covers curriculum, pedagogy, and assessment which stress the importance of standard or result [1] the implication is that syllabus and assessment development have to enable the students to demonstrate knowledge, and skill. The educational system applied to the students in competence based education largely determines students' success in learning achievement. This assessment process is often neglected in teaching. The assessment performed should not only in the form of final evaluation as to know the final learning achievement, but it should put more emphasis on learning process.

The birth of Curriculum 2013 (often its called K13) brings a reasonably great impact on the change in education in Indonesia. The impact on the change that occurs is not only in learning process but also in assessment process of the students. Assessment in K13 has shifted toward a better one, in which formerly it only measured competences in terms of learning achievement only (which used to use a test) toward authentic assessment which measures competences in attitude, skill and knowledge based on process and product. This assessment process also encourages the use of students' portfolios as a major assessment instrument. In relation to portfolio assessment, there is one thing which is very

\footnotetext{
*Corresponding author: k.setemen@undiksha.ac.id
} 
interesting, that is the existence of assessment and feedback given by peers and this is called peer assessment. Peer assessment is a process in which an individual assesses the number, level, value, or success of his or her peer [2]. The characteristics of peer assessment includes a process in which a members of a team assesses each other's work, thus, the goal setting has to be fully understood by the students. Peer assessment as an alternative assessment gives freedom to the students to express opinions. The assessment is based on performance (performance-based assessment) so that in the peer assessment learning also occurs, the students develop cognitive skill and social skill [3].

Research on assessment and evaluation have been done by many researchers in education sector. Setemen [4] did a research on developing online-teaching evaluation development. The functions that have been accommodated are to manage students' data, to manage test item data, and some system settings to regulate the user's accessing right. This on-line system has also been tried out with the students in small groups, and can be accepted well by the students as an assessment system which is computer-based.

Improvements in learning achievements of the students, in this case university students, cannot be separated from the types of assessment used in learning process. This was proven by the study conducted by Setemen [5], in which the study done was an experiment comparing the use of the portfolio assessment and project assessment in computer programming. The result of portfolio assessment was better than that of the use of project assessment in computer programming. It is pointed out strongly that in portfolio assessment process the assessment is done continuously.

From the result of assessment that has been shown it can be seen that assessment process plays an important role in learning, in which the assessment done is oriented toward the students. This agrees with the change in teaching process from teacher-oriented to student-oriented. This means that not only in learning the orientation is toward the students, but also as long as it is possible, in the assessment process the students can also be involved. Thus, recently, the terms self-evaluation and peer assessment started to be used. Actually, self-evaluation and peer assessment are elements in portfolio assessment. Regarding peer assessment, some researchers have also published research results. An example is the study conducted by Hämäläinen, et al. [6] in their study they applied peer review in the programming tasks. The benefits gained from the application of peer-review are: 1) the students can learn from other students and receive a feedback, and 2) the teacher is helped with the assessments that have been done by other students. Another study was done by Wing-Shui [7] on the effect of peer assessment and feedback strategy on computer programming course. The finding shows that the students felt satisfied with peer assessment and feedback strategy in Computer Programming Course. Besides, their performance was also better than those with the use of traditional teaching method.

From some studies that have been mentioned above, peer assessment or peer review has been conducted by using computer as an aid. However, the assessment process done was limited to the course material used by the researcher. In the study, the features in the application made has not expressed the followings: 1) whether the system can be used for materials for other teaching practices, 2) whether the assessment rubric can be used by other teachers and 3 ) whether the peer group formed is individual or a peer group.

\section{Method}

This research is research and development (R\&D) model. This study was a teaching assessment development done in two phases by adopting the 4D model (Define, Design, Develop and Disseminate). The first phase was determined as Define and Design phases, aiming to design a web (on-line) peer assessment prototype. In this first phase, the study started with a descriptive study which aimed to determine and to decide the conditions, 
empirical and theoretical prerequisites of Peer Assessment model which was going to be developed. The main activity was doing a series of need assessment. This need assessment activity would be done through library study and field survey. The next phase was Develop and Disseminate stage which was basically aimed to develop a model and its valid and reliable materials. The first activity is a limited model and its materials try-out. This was done through two activities. The first activity took the form of a limited try-out of the model and its materials. The second activity was a try-out in the form of an experimental research to test the strengths of the model and to see the effectiveness of its model.

\section{Results and Discussion}

\subsection{Define Phase}

In the define phase, a need assessment had been done. The need assessment took the form of a library research related to peer assessment and field survey which targeted SMA and SMK teachers from some schools in Buleleng Regency. The library study conducted aimed to compare some results of studies done by researchers in the computer and education sector which took the data from some scientific articles. This library study is important to see the position of the researcher in the study that would be done. After the study of some articles, it turns out that the related studies to the development of computerbased evaluation application that would only be used by the researcher. This means that if the application developed would be implemented in the material of other teaching materials, then modifications are needed in the application to be developed. Besides, in the developed application there has not been available a feature to share an assessment rubric. Thus, any if there is a topic that needs the same rubric, the teacher has to rebuild the rubric. Based on the analysis, it is clear that at this define phase, the most competitive feature in the prototype of assessment developed is that it can be used by anyone as a teacher who has to enlist in the system through the administrator. Another feature is the facility to share rubrics which enable the use of the same rubric among teachers for different teaching materials.

The second activity in the need assessment is field survey which targets teachers at SMA's and SMK's in various schools in Buleleng Regency, Bali. The number of the respondents in the field survey was 103 teachers. The survey was conducted by distributing questionnaires that are related to assessing students. There were 3 (three) important categories asked in the survey, namely: 1) planning the assessment, 2) assessment strategy, and 3 ) implementation of assessment. The description of each category and the result of the survey can be seen in Table 1, Table 2 and Table 3.

Table 1. Results of the survey about assessment planning by the teacher.

\begin{tabular}{|r|l|r|r|}
\hline \multirow{2}{*}{ No Statement } & \multicolumn{1}{|c|}{} & \multicolumn{2}{|c|}{ Percentage of answers } \\
\cline { 3 - 4 } & & \multicolumn{1}{|c|}{ Yes } & \multicolumn{1}{|c|}{ No } \\
\hline 1 & Always plans an assessment in the teaching process & $98 \%$ & $2 \%$ \\
\hline 2 & Involves teacher/ colleage in planning an assessment & $35 \%$ & $65 \%$ \\
\hline 3 & Uses standard guide in assessing & $94 \%$ & $6 \%$ \\
\hline 4 & Uses the existing assessment instrument/rubric in assessing & $90 \%$ & $10 \%$ \\
\hline 5 & Determines by oneself type and criteria of assessment & $26 \%$ & $74 \%$ \\
\hline 6 & Assessment criteria are open (communicating with the students) & $91 \%$ & $9 \%$ \\
\hline
\end{tabular}


Table 1 shows that the teacher has planned assessments well. However, in planning the assessment, the involvement of a teacher or colleague in planning is below $50 \%$. This can be seen from point 2 in Table 1, that the involvement of other teachers or colleagues in planning assessments is only $35 \%$. Besides, based on Table 1 point 5 , the teacher tends to determine by him/herself the type and criteria of assessment only $26 \%$. This occurred since the teacher in general uses the existing standard guide.

Table 2. Results of survey on assessment strategy used by the teacher.

\begin{tabular}{|c|l|c|c|}
\hline \multirow{2}{*}{ No } & \multicolumn{1}{|c|}{ Statement } & \multicolumn{2}{|c|}{$\begin{array}{c}\text { Percentage of } \\
\text { answers }\end{array}$} \\
\cline { 3 - 4 } & & Yes & No \\
\hline 1 & Assessment only involves the teacher & $58 \%$ & $42 \%$ \\
\hline 2 & Assessment involves other teachers in its process & $42 \%$ & $58 \%$ \\
\hline 3 & Assessment involves students in its process & $22 \%$ & $78 \%$ \\
\hline 4 & Gives the chance to students to assess him/herself & $21 \%$ & $79 \%$ \\
\hline 5 & $\begin{array}{l}\text { Give the change to a student to assess other student individually and in } \\
\text { group (peer group) }\end{array}$ & $26 \%$ & $74 \%$ \\
\hline 6 & $\begin{array}{l}\text { Assessment is done through the colllaboration of teacher, another teacher, } \\
\text { and students }\end{array}$ & $45 \%$ & $55 \%$ \\
\hline
\end{tabular}

Table 2 shows that in terms of strategy used by the teacher, the involvement of another teacher, and students in assessing is below $50 \%$ on average. This means that the teacher still plays the central role in his or her students' assessment process. Thus, the teacher has started to do an assessment by involving another teacher and students so that the assessment process is more objective. With the presence the students' assessment, then indirectly, the process of knowledge creation occurs in the students.

Table 3. Results of the implementation of scores done by the teacher.

\begin{tabular}{|c|l|r|r|}
\hline \multirow{2}{*}{ No } & \multicolumn{1}{|c|}{ Statement } & \multicolumn{2}{|c|}{$\begin{array}{c}\text { Percentage of } \\
\text { answers }\end{array}$} \\
\cline { 3 - 4 } & \multicolumn{1}{|c|}{ Yes } & \multicolumn{1}{c|}{ No } \\
\hline 1 & Assessment is done manually & $83 \%$ & $17 \%$ \\
\hline 2 & $\begin{array}{l}\text { Assessment is done with the aid of computer (for example, using Excel } \\
\text { application or the equivalent) }\end{array}$ & $88 \%$ & $12 \%$ \\
\hline 3 & Assessment is computerized (using the existing assessment system) & $24 \%$ & $76 \%$ \\
\hline 4 & Assessment is done through local network or wide network (on line) & $25 \%$ & $75 \%$ \\
\hline 5 & Assessment is just in a day (has to be complete at the time only) & $28 \%$ & $72 \%$ \\
\hline 6 & Assessment is done in a range of time & $91 \%$ & $9 \%$ \\
\hline 7 & Assessment is done manually & $83 \%$ & $17 \%$ \\
\hline
\end{tabular}

Table 3 shows that in implementing assessments of the students, many teachers have not used computer-based assessment system. This can be seen in Table point 3 , only $24 \%$ of teachers used computer-based assessment system.

\subsection{Design Phase}

After a library research was done and after analyzing needs related to peer assessment with self assessment features, the strong features in this computer-based peer assessment are: 1) a teacher can create the course; 2) The teacher can create the class to be taught; 
3) the teacher can create the group of assessments; 4) the teacher can create or choose rubrics to be used in assessing; and 5) the teacher can create or start assessment. Broadly, the design of the prototype of this computer-assisted peer assessment looks like the one shown in Figure 1.

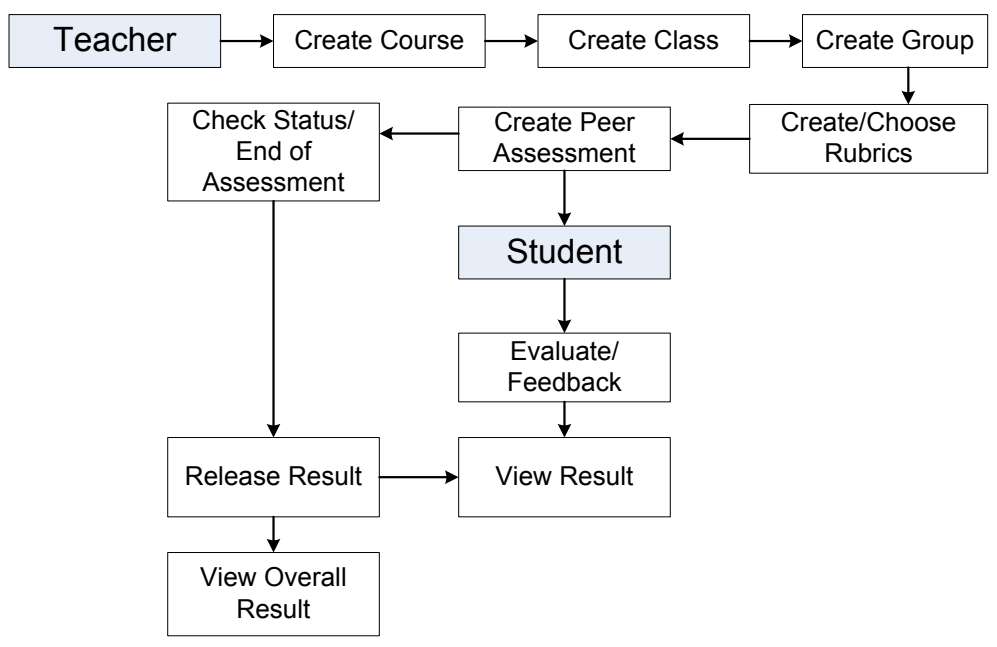

Fig. 1. The Flowchart of Peer Assessment.

Figure 1 shows the steps that have to be taken by a teacher in doing peer assessment. Before the teacher does peer assessment, he /she has to create the course first. The teacher can create more than one course. The next step is to create a class at this step, the teacher has to enter the class and class members who take the course which was created before. Every course created has to have a class and class members who take the course. After creating the course and class members, the next step is to create a group of assessors for peer assessment. The group of assessors created are both individuals and some individuals in a group. This group is automatically created by the system, according to the number of members per group who are entered by the teacher. The next step is to create an assessment rubric or to choose from the already existing ones. The creation of a rubric starts from the determination of components, weight of each component and its descriptor and its score range. In addition to creating a rubric, the teacher also has to choose or use a rubric that already existed before if it is still relevant. Then the teacher creates or maps out the assessment to be given to the group of assessors.

The task of the student is to do the assessment according to the map given by the teacher. In addition, he or she can also give comments on the work that he/she assesses. If the time for assessment is up, then the teacher will announce the results of all of the groups. Thus, the students can see the comments given on the works that they did. The comments given by the group of assessors will become inputs for every student to do correction to the materials that he/she has learned.

\section{Conclusion}

The process of assessment by using peer assessment needs much time and energy. This is caused by the great variation in the results produced in an assessment in which an individual can be assessed by a group of students so that the total number of the results become the square of the total number of the groups. Therefore, by developing the 
prototype of computer-based peer assessment it will help a teacher to correct and give a final assessment to a learning process. Computer in this process does not only serve as an aid but it has become part of the process of assessment. If this assessment application can facilitate the teacher in assessing the students in assessing the students, the assessment will become more transparent, quick and accurate. The peer assessment application is designed to be on-line based, so that it becomes an electronic assessment and can be accessed from anywhere and whenever as long as there is internet connection.

This research was funded by Ministry of Research, Technology, and Higher Education of the Republic of Indonesia.

\section{References}

1. H. B. Uno, Perencanaan pembelajaran (Bumi Aksara, Jakarta, 2011)

2. K. Topping, AERA 68, 249 (1998)

3. Rochmiyati, Jurnal Penelitian dan Evaluasi Pendidikan 17, 333 (2013)

4. K. Setemen, Jurnal Pendidikan dan Pengajaran 43, 207 (2010)

5. K. Setemen, Seminar nasional forum pimpinan pascasarjana LPTK indonesia (Undiksha Press, Singaraja, 2014)

6. H. Hämäläinen, V. Hyyrynen, J. Ikonen, J. Porras, Int. Jour. on I. T. \& S. 1, 3 (2011)

7. W. S. Ng, Informing Science and Information Technology 9, 17 (2012) 